$\begin{array}{ccc}\text { Türk Coğrafya Dergisi } & \text { Turkish Geographical Review } \\ & \text { www.tcd.org.tr }\end{array}$

\title{
Gökpınar Baraj Gölü’nün hissedilen sıcaklık değerleri üzerindeki etkisi
}

\author{
The effects of the Gökpinar Dam Lake (Denizli) on the heat index(HI)values
}

\author{
Selahattin Akşit*a (1) Cansu Duman ${ }^{\mathrm{b}}$ \\ ${ }^{a}$ Pamukkale Üniversitesi, Fen Edebiyat Fakültesi, Coğrafya Bölümü, Denizli. \\ ${ }^{b}$ Pamukkale Üniversitesi, Fen Edebiyat Fakültesi, Coğrafya Bölümü, Denizli.
}

ORCID: S.A. 0000-0002-9782-0245; C.D. 0000-0002-2170-7350

\section{BILGI / INFO}

Geliş/Received: 18.06 .2019

Kabul/Accepted: 29.04.2020

\section{Anahtar Kelimeler:}

Baraj Gölü

Hissedilen sıcaklık

Trend analizi

Mann-Kendall

Denizli

\section{Keywords:}

Dam Lake

Heat index

Trend Analysis

Mann-Kendall

Denizli

*Sorumlu yazar/Corresponding author:

(S. Akşit) aksit@pau.edu.tr

DOI: $10.17211 /$ tcd.579523

\section{Atif/Citation:}

Akşit, S. ve Duman, C . (2020). Gökpınar Baraj Gölü’nün hissedilen sıcaklık değerleri üzerindeki etkisi. Türk Coğrafya Dergisi (74), 7-15.

DOI: $10.17211 /$ tcd. 579523

\section{ÖZ / ABSTRACT}

Çalışmanın amacı; Gökpınar baraj gölü yapımı öncesi ve sonrası meteorolojik verilerin istatistiksel olarak değerlendirilip gölün hissedilen sıcaklığa olan etkisini analiz etmektir. Enerji üretimi, sulama gibi amaçlara hizmet etmek için kurulan barajların, yararlarının yanında çevreye ve iklime olan etkileri de konuşulmaktadır. Yapılan çalışmalar da büyük su yüzeylerinin iklim üzerinde etkileri olduğu saptanmıştır. Bu çalışma da Denizli ili içerisinde bulunan 2002 yılında faaliyete geçmiş Gökpınar Baraj Gölü’nün iklim üzerindeki etkisi incelenmiştir. Çalışmanın veri seti Denizli Merkez ve Acıpayam meteoroloji istasyonlarından sağlanmıştr. Veriler barajın faaliyete geçtiği tarihten öncesi 19802002 ve 2002-2017 sonrası olmak üzere iki ayrı veri setini kapsamaktadır. Bu veri setindeki ortalama sıcaklık, ortalama bağıl nem ve bu verilerden hesaplanan ortalama hissedilen sıcaklık verileri analiz edilmiştir. Baraj yapılmadan önce ve sonra oluşan mutlak değişimler grafiksel analiz yöntemleri, bağımlı değişkenlerde t testi, Mann-Kendall ve Sen Trend Eğim Metodu ile istatiksel anlamda değişimin olup olmadığı ve değişim trendinin hangi yönde olduğu değerlendirilmiştir. Sonuçta çevre ikliminin ortalama sıcaklık ve hissedilen sıcaklık değerlerinde uzun dönemde artan yönde anlamlı bir değişimin olduğu, ortalama bağıl nemde ise azalan yönde anlamlı bir değişim olduğu belirlenmiştir. Fakat Denizli ve Acıpayam verileri karşılaştırıldığında aynı sonuçlara ulaşılmıştı. Bu ise değişimin baraj kaynaklı olmadığı iklimsel değişimle ilgili olduğunu göstermektedir..

The aim of the study is to analyze the meteorological data before and after Gökpınar dam lake construction and the effect of the lake on the heat index. The dams built to serve purposes such as energy production and irrigation, as well as the benefits of the them and their effects on the climate and environment are also being discussed. Studies have also shown that large water surfaces have an impact on the climate. In this study, the impact of Gökpınar Dam Lake, which was constructed in Denizli province in 2002, was investigated on climate. The data set of this study was provided from Denizli Central Meteorology Station. The data includes two separate datasets before 19802002 and after 2002-2017, when the dam was constructed. Mean temperature, mean relative humidity and mean heat index in these data sets have been analyzed. Absolute changes occurring before and after dam construction were evaluated by using graphical analysis methods, paired sample t test, Mann-Kendall and Sen's slope estimate trend analyses. These tests were used to determine whether there is a statistical change and the direction of change trend. As a result, it has been determined that there is a significant change in the mean temperature and heat index values of the environmental climate in the long term in the increasing direction and a significant change in the mean relative humidity in the decreasing direction. However, the same results were obtained when Denizli and Acıpayam data were compared. This shows that the change is related to the climatic change where the dam is not. 


\section{Giriş}

Tarih boyunca su, tüm canlılar için önemli olmuştur. Nüfusun artışı, sanayi, tarım gibi ekonomik faaliyetlerin gelişmesiyle akarsulardan daha etkili yararlanmak için önüne set çekilerek barajlar inşa edilmeye başlanmıştı. Önceleri sadece su temini için kullanılan barajlar günümüzde enerji üretiminden taşkın kontrolüne kadar birçok alanda fayda sağlamaktadır. Baraj yapımındaki artışa bağlı olarak da büyük su kütlelerinin çevreye yaptıkları ekolojik, meteorolojik, sosyal ve ekonomik etkiler araştırılmaya başlanmıştr.

Büyük su kütleleri bulundukları bölgenin iklimini etkilediğine dair birçok çalışma yapılmıştr. Özellikle kurak ve yarı kurak iklime sahip olan bölgelerde bulunan baraj yüzeylerinin üzerinden geçen hava kütlesiyle etkileşime girerek bölge ikliminde değişiklik yaptığı saptanmıştır (Güldal ve Ağıralioğlu, 1994, Kadıoğlu, Satılmış, ve Özgüler, 1994). Yapılan çalışmalarda ortak nokta baraj yapımı öncesi ve sonrası elde edilen meteorolojik verilerin karşılaştrılması ve anlamlı bir değişiklik olup olmadığının incelenmesine dayanmaktadır. Baraj göllerinin kapladıkları alan barajların yapılış amaçlarına göre farklılık göstermektedir. 1950'li yıllardan beri baraj haznelerinin boyutunda artş gözlenmiştir (Chao, 1995). Örneğin su depolama kapasitesi bakımından dünyanın en büyük barajlarından biri olan Zambiya ile Zimbabve sınırındaki Kariba barajı, 185 milyar m3 su depolamakta ve baraj yüzeyi 5,580 km2lik alanı kaplamaktadır. Bu denli büyük bir su kütlesinin özellikle kurak ve yarı kurak bölgelerde çevre iklimine etkisi yadsınamaz. Vaha etkisi olarak bilinen bu durum, barajların su tutmaya başlamadan öncesine kıyasla, yazların daha serin kışların ise daha ılıman geçmesini sağlamaktadır. Su yüzeyi ve hava kütlesi arasındaki farklı su buharı basınçları nedeniyle göl yüzeyinden karalara doğru nem transfer olmaktadır. Ayrıca havadaki nemin artmasıyla çevrede görülen sis, don, kar yağışı gibi iklim olaylarında artşlar görülmektedir (Kadıoğlu, Satılmış, ve Özgüler, 1994). Büyük su kütlelerinin bulunduğu ortamın iklimine etkilediğine dair yapılan çalışmalarda genel olarak sıcaklığın değiştiği görülmektedir. Suyun ısı kapasitesi hava ve toprağa göre daha fazladır. Bunun yanında suyun donma ve buharlaşma olayları sırasında depoladığı ısı da oldukça yüksektir. Bu yüzden su kütleleri bahar ayları ve günün erken saatlerinde olduğu gibi sıcaklığın hızla artmaya başladığı zamanlarda serinletici etki yapmaktadır. Sonbahar ve akşam saatleri gibi hava sıcaklığının hızla düştüğü zamanlarda ise çevrede ısıtıcı bir etki yapar. Serin yaz gecelerinde su kütlesinin yakınındaki hava ılıklaşırken, su kütlesinin ısısı yüzeydeki sıcaklık dalgalanmalarını azaltır. Örneğin barajsız bir vadide gündüz hava sıcaklığı vadi tabanında yükselmiştir ve yamaçtan yukarı çıktıkça azalır. Baraj yapımından sonra ise su kütlesi gündüzleri serinletici etki yapmakta hava sıcaklığı su yüzeyine yakın yerlerde azalmaktadır. Yamacın ortalarında ise sıcaklıklar en yüksek seviyelere ulaşır. Geceleri ise baraj yapımından önce hava sıcaklığı vadi tabanında en düşük seviyelerdeyken yamaç ortalarında en yüksek seviyelerdedir. Baraj yapımından sonra sıcaklık su yüzeyinde maksimum yamacın üst taraflarına doğru ise minimum seviyelerde olduğu görülmektedir. Aynı zamanda su kütlelerine yakınlaştıkça toprak sıcaklığı artmaktadır (Jermar, 1987'dan akt. Demirpençe ve Güldal, 2001).

Büyük su kütlelerinin iklim üzerindeki etkilerini ortaya koymak için yapılan çalışmalardan bir diğeri de Thornthwaite'ın Rubinsky Baraj gölünde yapılan çalışmadır. Thornthwaite bu çalışmada Rusya'da bulunan baraj gölünün sıcaklığa etkisinin çok az olduğu, sadece göl kıyısında rüzgar hızının iki kat arttı̆̆ belirtilmiştir (Kadıoğlu, Satılmış, ve Özgüler, 1994). Kuzey Amerika'da bulunan 92 büyük baraj gölünün iklim üzerindeki etkilerini inceleyen çalışmada; Akdeniz ve yarı-kurak iklimlerin hakim olduğu bölgelerde büyük baraj göllerinin iklimi daha çok etkilediği belirtilmiştir (Degu, Hossain , Niyogi, Pielke, ve Shepherd, 2011). Hindistan'da yapılan bir çalışmada ise barajların yeraltı suyunun miktarını arttırdığını, nehirlerin kuru mevsimlerde kapasitesinin arttğını ve orman vejetasyonuna olumlu katkıları olduğu vurgulanmıştır. Bu sayede de dolaylı yoldan barajların iklim değişikliğinin olumsuz etkilerini hafiflettiği söylenmiştir (Agoramoorthy ve Hsu, 2016). Gyau-Boakye (2001) ise Volta Nehri'nin iki büyük kolunda Akosombo Barajı yapımı sonrasında akımlarda düşmeler olduğunu saptamıştır. Ayrıca Volta Nehri'nin üst kısımlarında sıcaklıklarda $10^{\circ} \mathrm{C}^{\prime}$ lik bir artı̧̧ olduğu belirlenmiştir.

Tonbul (1986) çalışmasında Keban Barajı́nın bulunduğu bölgeye olan etkilerini ve baraj yapımından önce ve sonrasında iklim elemanlarını fraktal analiz yöntemleriyle incelemiştir. Araştırmacı çalışmanın sonucunda büyük su kütlelerinin çevreye olan etkisini analiz edebilmek için en az 25-30 yıllık bir sürenin geçmesi gerektiğini vurgulamıştır. "Son Değerlendirmeler Işığında Keban Barajı'nın Elazığ İkimine Etkisi”ni ortaya koymak için (Şengün, 2007)'ün yaptığı çalışmada ise baraj yapımından sonra geçen 30 yıllık süreç içerisinde iklim elemanlarında ekstrem bir değişiklik olmadığını sadece kış aylarında az da olsa bir ılımanlaşmanın olduğunu belirtmektedir. Keban Baraj Gölü'nün iklime olan etkisini araştıran bir diğer çalışma da ise gölün çevresindeki meteoroloji istasyonlarından alınan veriler analiz edilmiştir(Kadıoğlu ve Şen, 1994). Çalışmada meteorolojik verilerin homojen olup olmadığı fraktal analiz yöntemiyle analiz edilmiştir. Güldal ve diğ. (1994) yaptığı çalışmada ise Keban Barajı́nın yakın çevre iklimine etkisi olduğunu, kışın sıcaklıkların artıp yazın da nem yüzdelerinde artı̧ olduğunu tespit etmişlerdir. Başka bir çalışmada Kadıoğlu ve diğerleri (1994) büyük su yapılarının çevre iklimine etkisini ortaya koymak için Keban Baraj gölü çevresindeki iklim parametrelerine MannKendall istatistiğini uygulamıştır. Yapılan analizler sonucunda da Keban Barajının doğu kıyısında genelde yüksek sıcaklıkların azaldığı düşük sıcaklıkların ise artth̆ı tespit edilmiştir. Özkan (1996) Keban Baraj Gölü’nün iklime etkisi araştıran bir diğer araştırmacıdır. Araştırmacı bu çalışmada baraj yapımından sonra kış aylarında sıcaklık değerlerinde kayda değer artışlar, yaz aylarında ise bir miktar azalma tespit etmiştir. Birden fazla baraj gölünün bulunduğu yörenin iklimine etkisini ortaya koymak için Erdaş ve diğerleri (2001) Kahramanmaraş yöresindeki barajları incelemişlerdir. Yapılan araştırmalar sonucunda minimum sıcaklıkların arttığı, maksimum sıcaklıkların azaldığı, yağış miktarının artarak, ortalama rüzgar hızının düştüğü tespit edilmiştir. Türkiye'nin en büyük üçüncü gölü konumunda olan Atatürk Baraj Gölü’nün bulunduğu yörenin iklim şartlarına etkisini ortaya koymak için Yeşilnacar ve Gülşen'in (1999) yılında yaptı̆̆ çalışmada, sıcaklıklarda önemli bir değişikliğin olmadığı fakat bağıl nem oranlarının Nisan-Ekim ayları arasında arttğı saptanmıştır. Aynı zamanda bu çalışmada Keban ve Atatürk barajlarının aynı havzada bulunmalarına rağmen iklim parametreleri üzerinde yaptığı değişiklikler ele alınırken barajların bulunduğu yöreleri ayrı ayrı alarak inceleme yapılması gerektiği vurgulan- 
mıştır. Yapılan başka bir çalışmada ise su kütlesinin olduğu yerde nem artışının olması da beklendiği vurgulanmıştır. Baraj yapımından önce bir vadide yamaç tepesi ile yamaç tabanı arasındaki nisbi nem oranı \%3 civarındayken, baraj yapımından sonra yamaç tabanında \%10-15 oranında nemin arttı̆ı gözlemlenmektedir. Ayrıca baraj gölü yüzeyinde oluşan nem hava hareketi nedeniyle göl üzerinde sis oluşturur. Özellikle rüzgarsız havalarda baraj gölü ve çevresinde sis olayı görülebilmektedir (Xiutai, 1986)nem hava hareketi nedeniyle göl üzerinde sis oluşturur. Özellikle rüzgarsız havalarda baraj gölü ve çevresinde sis olayı görülebilmektedir (Xiutai, 1986).

Sadece büyük su kütlelerinin değil kapladığı alan bakımından küçük barajların da bölge iklimine yaptiğı değişiklikler de araştırmacılar tarafindan çalışılmıştır. Batan (2012) Ilısu Baraj Gölü'nün Diyarbakır ve Batman illerinin iklimine etkisini lineer regresyon yöntemleriyle incelemiştir. İncelemeler sonucunda da sıcaklıkta kısmi artış ve azalışlar, nisbi nemde genelde azalmalar, buharlaşmada da kış aylarında azalma tespit edilmiştir. Arslan (2017) yine yarı kurak bir iklime sahip olan Niğde ilinde bulunan Akkaya Barajı́nın iklime olan etkisini incelemiştir. Baraj sonrasında aylık toplam yağış miktarlarının ve aylık minimum sıcaklık değerlerinin arttğı, aylık ortalama nispi nem ve aylık ortalama rüzgar hızının azaldığını tespit etmiştir.

Bu çalışmada incelenecek olan Gökpınar Baraj Gölü ise Bacanlı ve Tuğrul tarafindan (2015) trend analiz yöntemleri (lineer regrasyon, Mann Kendall ve Sen) kullanılarak yıllık maksimum, minimum, ortalama sıcaklık, rüzgar hızı, yağış ve buharlaşma verilerindeki değişimleri analiz edilmiştir. Çalışmanın sonucunda yapılan tüm analizlerde sıcaklıkta artş gözlenmiştir. Ancak bu artş̧ı sadece baraj gölünün varlığıyla açıklamak mümkün değildir diye ekleyen araştırmacılar, sıcaklık değişimlerini küresel iklim değişikliğinin Akdeniz iklimi üzerindeki etkisi olabileceğini vurgulamışlardır.

Literatürde "Heat Index (HI)" olarak geçen hissedilen sıcaklık, günlük hayatta insan vücudunun algıladığı sıcaklıktır (Steadman, 1979a; Steadman, 1984; Rothfusz, 1990; Stapleton, ve diğerleri, 2016; Golbabaei, ve diğerleri, 2019). Bu sıcaklık kavramı kişinin vücut yapısı, giysilerin ısı direnci, bulunduğu iklim gibi kavramların yanında termometre sıcaklığı, nisbi nem, rüzgar ve radyon gibi iklim elemanlarından da etkilenen sübjektif bir kavramdır. Bu yüzden sıcaklık algılama ve hissetme kişiden kişiye değişebilmektedir. Termometre sıcaklığı, nisbi nem ve rüzgar gibi meteorolojik parametreler insanın hissettiği sıcaklıkta önemlidir fakat radyasyon diğerlerinden daha farklıdır. Örneğin bir kişi oda sıcaklığı $20^{\circ} \mathrm{C}$ 'de eğer dışarısı da $20^{\circ} \mathrm{C}$ " ise üşüdüğünü hissetmez. Fakat dışarısı $20^{\circ} \mathrm{C}$ 'den düşük ise ortamdaki radyasyon kaybı nedeniyle kişi üşümeye başlar. Bu yüzden insan vücudunun hissettiği sıcaklık alınırken ıslak hazne hava sıcaklık değeri alınmaktadır. Sıcak havalarda yaptığımız etkinliklerin seviyelerin, giysilerin ısı direnci, ortalama radyant sıcaklık, havanın su buharı basıncı, bağıl hava hızı ve çevre sıcaklığı daha çok hissetmemize neden olabilir. Soğuk havalarda ise özellikle hava sıcaklığının sıfirın altına düştüğü durumlarda kuvvetli rüzgar havanın daha soğuk hissedilmesine neden olmaktadır. Bu sıcaklığı da "üşüme sıcaklığı" denmektedir (MGM, 2018).
Herkesin sıcaklığı farklı hissediyor olması hissedilen sıcaklık teriminin bilimsel olarak açıklanamayacağı sonucu çıkarmaz. Tüm bilimsel çalışmalarda olduğu gibi hissedilen sıcaklık değerleride alınırken uç kıstaslara değil ortalama değerlere başvurulmuştur.Hissedilen sıcaklığın bilinmesi kişinin biyoklimatik konfor seviyesini belirlemenin yanında, sağlık açısından önemli sonuçlara sebep olabilecek durumların önceden tahmin edilip tedbir alınmasını da sağlamaktadır (MGM, 2018). Yapılan bir araştırmada bir kişi çıplak olarak 29 ile $31^{\circ} \mathrm{C}$ sıcaklıkları arasında, giyinik olarak ise 23 ile $27^{\circ} \mathrm{C}$ sıcaklıkları arasında bir ortamda hareketsiz bulunduğu durumlarda vücuda Isı geçişi ve vücuttan buharlaşma ile ısı kaybı yoktur. Kişi denge sıcaklığındadır ve fizyolojik denetim mekanizmaları normal vücut sıcakIığını korumak için devreye girmezler (Ashrae, 1997). Bu değerlendirme de deneklerin iç mekanda 25 yaşlarında, sağlıklı, normal giyinmiş ve hareket etmeyen kişiler olduğu kabul edilmiştir. Sungur’a (1980) göre Türkiye için yapılan bir araştırmada insanın kendini rahat hissedebileceği sıcaklık değerleri 16,7 ile $24,7^{\circ} \mathrm{C}$ arasındadır.

Enerji üretimi, sulama gibi amaçlara hizmet etmek için kurulan barajların, yararlarının yanında çevreye ve iklime olan etkileri de konuşulmaktadır. Yapılan çalışmalar da su yüzeylerinin iklim üzerinde etkileri olduğu saptanmıştır.

Bu çalışmanın amacı Denizli ili içerisinde bulunan 2002 yılında faaliyete geçmiş bulunan Gökpınar Baraj Gölü'nün hissedilen sıcaklığa olan etkisini analiz etmektir. Bu amaçla çalışmada, 1980-2017 yılları arasında Denizli ilinde bulunan istasyonlara ait yıllık ve aylık iklim parametreleri çeşitli istatiksel yöntemler kullanılarak incelenmiştir.

\section{Materyal ve Yöntem}

Denizli ili Ege ve Akdeniz bölgelerinde toprakları olan bir ildir.Aydın, Manisa, Afyon, Burdur, Isparta, Uşak ve Muğla illerine komşudur. İl merkezinin denizden yüksekliği 345 metre olup, ilin en yüksek noktası 2.571 metre ile Honaz Dağı'dır. Denizli'nin doğusunda Honaz Dağı, kuzeyinde Çökelez Dağı, güneyinde ise Akdağ ve Babadağ ile çevrili olup, il merkezi Honaz Dağı eteklerinde çanak şeklindeki ovada bulunmaktadır (Şekil 1).

Çürüksu akarsuyunun bir kolu olan Gökpınar Deresi üzerinde kurulan Gökpınar Baraj Gölü; Büyük Menderes Havzası'nın alt havzası olan Çürüksu Havzası'nda bulunmaktadır. Bölge yıl boyunca tek bir hava kütlesinin etkisi altında değildir. Genel olarak yazın tropikal, kışın ise kutbi ve arktik hava kütlelerinin etki sahasına girer (Göney, 1975). Bu nedenle genel manada yazlar sıcak ve kurak, kışlar ılık ve yağışlıdır. Kış aylarında kuzeyden Akdenize doğru sokulan batılı ve kuzeybatılı hava kütleleri(mP) Balkanlar ve Ege denizi üzerinden geçerek Akdeniz üzerinde IsInır ve nisbi nemi arttırır. Böylelikle ani sıcaklık değişimleri ve frontal yağışlar görülür. Yazın ise bölge sıcak kökenli kontenantal tropikal (cT) karalar üzerinden geçerek ısınmakta ve giderek kuraklaşmaktadır (Koçman, 1993). 

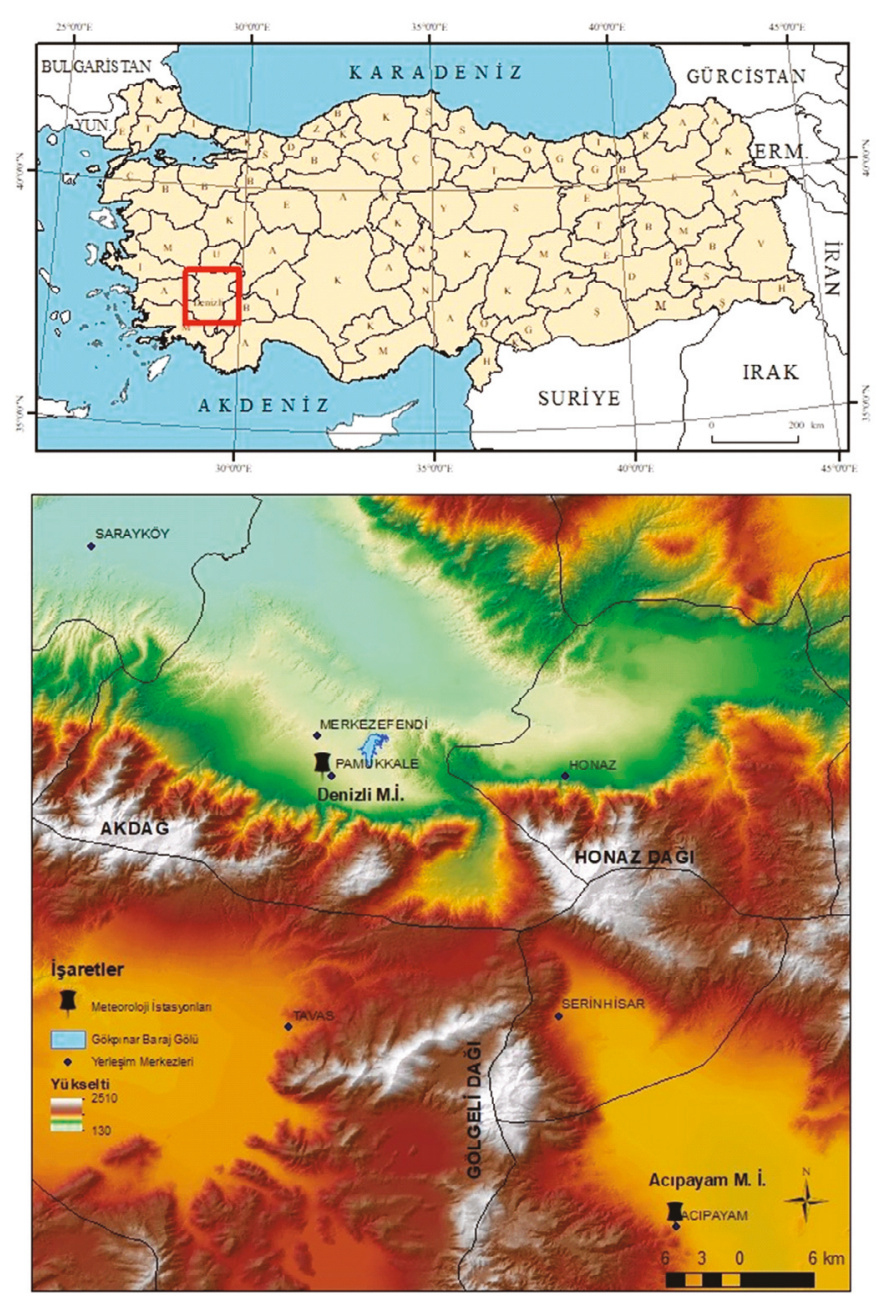

Şekil 1. Gökpınar Baraj Gölü ve meteoroloji istasyonlarının konumu

Figure 1. Location of Gökpınar Dam Lake and meteorological stations

Denizli'de karakteristik Akdeniz iklimi hakimdir. Fakat denizden uzaklık ve yükseklik etkisiyle Akdeniz iklimi değişikliğe uğramıştır. Yazlar çok sıcak olmakla birlikte kışlar Akdeniz ikliminin hâkim olduğu diğer yörelerden daha soğuk geçmektedir. Kış yağışları nispeten az olmakla birlikte yağışın yıl içerisindeki payı ilkbaharda daha fazladır. Denizli güneyinde bulunan Akdağ, Honaz gibi yükseltilerin olması güneyden gelen hava kütlelerinin iç kesimlere girmesini zorlaştırmaktadır. Ege koridorları boyunca gelen sıcak hava akımları ise Akdeniz iklim şartlarının etkisini arttırmaktadır. Yükselti arttkça da yazlar daha serin, kışlar da bol kar yağışlı geçmektedir (Darkot ve Tuncel, 1995). Bu çalışmada 425 metre rakımındaki Denizli İstasyonu ve 941 metre rakımındaki Acıpayam istasyonlarına ait veriler kullanılmıştır.

Gökpınar Baraj Gölü 1995-2002 yıllarında inşa edilmiş bir barajdır. Baraj sularını il içi uzunluğu $38 \mathrm{~km}$, debisi 2,86 m3/sn olan Gökpınar deresinden almaktadır. Dere Denizli'nin 9 km kuzeyinde sona erer ve Çürüksu'ya dökülür (IÇDR, 2016). Gökpınar kaynaklarının Denizli şehrine içme suyu olarak temini ve baraj mansabında bulunan Akköy, Pamukkale, Karahayıt, Aşağışamlı ve Sığma belediyelerine yıllık $3 \mathrm{hm} 3$ içme suyu tahsisi ayrıca da Çürüksu ovalarının sulama sahalarına su temini amaçlanarak inşa edilmiştir. Barajın bir diğer amacı ileride Denizli ili içme ve kullanma suyu ihtiyacı için yetersiz kalabileceği düşüncesi ile alternatif kaynak olmasıdır.
Kil çekirdekli toprak dolgu tipi olan barajın göl hacmi 27,72 hm3, akarsu talveginden uzaklığı 43 metredir. Baraj rezervuar yüzeyi 198 ha'dir (IÇDR, 2017).Ayrıca baraj 5.824 hektarlık bir alana sulama hizmeti vermektedir. Pamukkale ilçesinde yer alan Gökpınar Baraj Gölü il merkezine kuş bakışı 4 km uzaklıkta bulunmaktadır (IÇDR, 2017).

Bu çalışmada Gökpınar Baraj Gölü'nün yapımından sonra hissedilen sıcaklığın ne yönde değişim gösterdiğini incelemek amacıyla Türkiye Devlet Meteoroloji Genel Müdürlüğü’nden Denizli ve Acıpayam istasyonlarına ait 1980-2017 yıllarını kapsayacak şekilde aylık ortalama sıcaklık ve aylık ortalama bağıl nem verileri temin edilmiştir. İki istasyon için de veriler baraj gölünün faaliyete geçtiği 2002 yılı baz alınarak baraj yapımı öncesi (1980-2002) ve baraj yapımı sonrası (2002-2017) olarak ikiye ayrılmıştır. Denizli istasyonun konum itibariyle baraj gölüne yakın olması ve en az 30 yıllık veri sağlayabiliyor olması nedeniyle bu çalışmada kullanılmıştır. Barajın konumuna yakın olan Pamukkale (Bağbaşı), Pamukkale (Akköy), Honaz, Sarayköy istasyonlarının barajın yapım tarihi olan 2002 yılından sonra faaliyete geçmiş olması, barajın iklime olan etkilerini inceleyebilmek için baraj yapımı öncesi yıllara ait verilerin bulunmaması ve gözlem süresinin 30 yıldan daha kısa olduğu alanlarda iklim değişimlerini ortaya koymak çok anlamlı olmadığı için çalışmada bu istasyonlara ait veriler kullanılmamıştır. Barajın konumuna uzak olan Acıpayam istasyonu verileri ise iklim parametrelerindeki değişimlerin küresel iklim değişiminden kaynaklı olup olmadığını araştırmak için çalışmaya dahil edilmiştir. Değerlendirme yapılırken 2 istasyona ilişkin istatistiksel analiz sonuçları karşılaştırılmıştır.

Çalışmada Denizli ve Acıpayam istasyonlarına ait 1980-2017 yılları arasındaki aylık ortalama sıcaklık ve aylık ortalama bağıl nem verileri alınarak aylık ortalama hissedilen sıcaklık değerleri bulunmuştur. Hissedilen sıcaklık hesaplamaları yapılırken şu formül kullanılmıştır (Steadman, 1979; NOAA, 2014);

$\mathrm{HI}=\mathrm{C} 1+\mathrm{C} 2 \mathrm{~T}+\mathrm{C} 3 \mathrm{RH}+\mathrm{C} 4 \mathrm{TRH}+\mathrm{C} 5 \mathrm{~T} 2+\mathrm{C} 6 \mathrm{RH} 2+\mathrm{C} 7 \mathrm{~T} 2 \mathrm{RH}+\mathrm{C} 8 \mathrm{TR} 2+\mathrm{C} 9 \mathrm{~T} 2 \mathrm{RH} 2$

$$
\begin{array}{lll}
\text { HI=Hissedilen Sicaklık } & \text { T=Sicaklık, } & \text { RH= Bağ1 Nem } \\
\mathrm{C} 1=-42,379 & \mathrm{C} 4=0,22475541 & \mathrm{C} 7=1,22874 \times 1^{3} \\
\mathrm{C} 2=2,04901523 & \mathrm{C} 5=6,83783 \times 1^{3} & \mathrm{C} 8=8,5282 \times 10^{-4} \\
\mathrm{C} 3=10,1433317 & \mathrm{C} 6=5,481717 \mathrm{x}^{2} & \mathrm{C} 9=-1,99 \times 10^{-6}
\end{array}
$$

Formülde hissedilen sıcaklık değerini bulmak için (T) kuru termometre sıcaklık değeri ve (RH) bağıl nem değerleri formülde verilen katsayılar ile toplanır. Çalışmada hesaplanan aylık ortalama hissedilen sıcaklık değerleri baraj yapımı öncesi (19802002) ve baraj yapımı sonrası (2002-2017) olarak ikiye ayrılarak analizlere dahil edilmiştir.

Gökpınar Baraj Gölü'nün bölge iklimini ne yönde etkilediğini belirlemek amacıyla üç ayrı istatiksel metot uygulanmıştır. illki, iklim parametreleri arasındaki farkların belirlenmesi ve değişimin olup olmadığının tespiti için bağımlı gruplarda t testi (t-student) uygulanmıştır. Bölgedeki barajdan kaynaklı iklim değişikliğini trendini belirlemek ve istatiksel anlamda önemli bir artma ya da azalma olup olmadığını belirlemek için trend analizi yöntemlerinden Mann-Kendall ve Sen Trend Eğim Metodu kullanılmıştır. 
Bağımlı gruplarda t testi ( $t$-student) ilişkili olan iki bağımlı grubun ortalamaları arasında manidar bir farklılık olup olmadığının test edilmesinde kullanılır. Bu test baraj yapımı öncesi ve sonrası olarak ayrılan aylık ortalama sıcaklık, aylık ortalama nisbi nem ve aylık hissedilen sıcaklık ortalaması iklim parametreleri baz alınarak analiz edilmiştir. Her bir parametre için değişkenlerin fark puanları hesaplanmış ve normal bir dağılım gösterdikleri çarpıklık ve basıklık değerleri baz alınmıştır. $t$ test sonucunda değişkenler arasında anlamlı bir farklılık olup olmadığı p>0.05| Ho: RET önermesiyle değerlendirilmiştir.

Bu çalışmada kullanılan Mann-Kendall Testi ve Sen Trend Eğim Metodu; Dünya Meteoroloji Örgütü tarafindan önerilen hidroloji ve klimatoloji alanlarında sıkça kullanılan parametrik olmayan istatiksel test yöntemleridir (Gilbert, 1987; Esterby, 1996). Özellikle Mann-Kendall Testi iklim değişikliği tespiti çalışmalarında sıkça kullanılmaktadır. Mann (1945) tarafindan geliştirilen bu test Kendall's Tau (Kendall, 1975) olarak bilinen testin özel bir uygulamasıdır. Bu test klimatolojik ve hidrolojik veriler gibi genellikle kısa süreli, içerisinde eksik verileri barındıran, çarpık dağılıma sahip veri serilerindeki eğilimi tespit etmek için kullanılır (Hirsch, Slack, ve Smith, 1982).

Mann- Kendall Testi uygulanırken ilk olarak S'nin başlangıç değeri 0 olarak belirlenir. Her bir veri kendinden sonraki veri ile kıyaslanır ve veri bir sonrakinden küçük ise $S$ bir arttrılır, büyük ise $S$ bir azaltılır (Anonim, 2019).

$$
S=\sum_{i=1}^{n-1} \sum_{j=k+1}^{n} \operatorname{sign}\left(x_{j}-x_{i}\right)
$$

Trendin anlamlılığını belirlemek için normalleştirilmiş z istatistiği şu formül ile hesaplanır:

$$
z=\left\{\begin{array}{rr}
(S-1) / s e, & S>0 \\
0, & S=0 \\
(S+1) / s e, & S<0
\end{array}\right.
$$

Z istatistiğinin varyansı ise (var) şu formülle hesaplanır:

$$
\text { var }=\frac{1}{18}\left[n(n-1)(2 n+5)-\sum_{t} f_{t}\left(f_{t}-1\right)\left(2 f_{t}+5\right)\right]
$$

Test sonucunda sıfir hipotezi zaman serisinde trend yok anlamına gelirken; alternatif hipotez ise zaman serisinde trend var anlamına gelmektedir. \%95 aralığında; eğer $|z|>1.96$ ise sıfir hipotezi reddedilir. Elde edilen z değeri negatif ise azalan yönde bir trend, pozitif ise artan yönde bir trend vardır (Temur, 2017).

Sen (1968) tarafindan Kendall's Tau istatistiği geliştirilerek oluşturan Sen Trend Eğim Metodu (Sen's Slope) doğrusal bir trend mevcut ise birim zamandaki değişim miktarının tespiti için kullanilır.
Bu test için $\left(X_{1}, X_{2} \ldots \ldots . . ., X_{n}\right)$ zamana göre sıralanmış veriler ise $X_{j}$ ve $X_{k}$ (j>k olmak şart ile) değerleri aşağıdaki formül kullanılarak trend eğimi bulunur. N sayısının tek olması durumunda (1) formülü, çift olması durumda (2) formülü kullanılır. Bu değerin pozitif olması artan yönde, negatif olması ise azalan yönde bir eğilimin olduğunu gösterir (Zaiontz, 2012).

$$
\begin{aligned}
Q_{i} & =\frac{\left(x_{j}-x_{k}\right)}{(j-k)} \\
Q & =Q_{(N+1) / 2} \\
Q & =\left\{\frac{1}{2}\left[Q_{N / 2}+Q_{(N+2) / 2}\right]\right\}
\end{aligned}
$$

Bu çalışmada Denizli ve Acıpayam meteoroloji, istasyonundan 1980-2017 yılları arası temin edilen aylık ortalama sıcaklık, aylık ortalama nisbi nem ve aylık hissedilen sıcaklık ortalaması iklim parametreleri baraj öncesi ve sonrası olarak ikiye ayrılmış ve Mann-Kendall testi uygulanmıştır. Çıkan sonuçlar aylık ve yıllık ortalamalar bazında değerlendirilmiş ve trendin olup olmadığı ve önemli bir artma ya da azalma eğilimi olup olmadığı analiz edilmiştir. Veriler \%95 güven aralığında normal dağılımın 0.05 anlamlılık düzeyinde $|z|>1.96$ 'dan önermesi baz alınarak değerlendirilmiştir. Mann-Kendall testinde kullanılan parametreler Sen Trend Eğim Metodu'nu uygularken de kullanılmıştır.

\section{Bulgular ve Tartışma}

Denizli ve Acıpayam meteoroloji istasyonu iklim parametreleri baraj yapımı öncesi ve sonrası olmak üzere iki döneme ayrılarak Şekil 2'de aylık ve yıllık ortalamalar olarak verilmiştir. Denizli istasyonunda baraj yapımı öncesi (1980-2002) yılları arasında yıllık ortalama sıcaklık $16^{\circ} \mathrm{C}^{\prime}$ dir. Baraj yapımından sonra (2002-2017) ise $17^{\circ} \mathrm{C}$ olduğu görülmektedir. Yıllık ortalama nisbi nem ise baraj yapımında önce $\% 61,4$ iken, sonrasında \%55,8'e düştüğü görülmektedir. Denizli istasyonunda baraj yapımından sonra ki geçen 15 yıllık periyotta ise sıcaklıkların hemen hemen tüm aylarda arttı̆ı görülmektedir. Aylık ortalama sıcaklığın en yüksek olduğu ay $28,7^{\circ} \mathrm{C}$ ile Temmuz ayıdır. Bu da Akdeniz iklim karakteristiği olarak kışların ılık geçtiğini göstermektedir. Acıpayam istasyonunda ise baraj yapımı öncesi yıllık ortalama sıcaklık $12,5^{\circ} \mathrm{C}$ iken baraj yapımından sonra $13,5^{\circ} \mathrm{C}$ 'ye yükseldiği tespit edilmiştir. Baraj öncesi dönemde aylık ortalama nisbi nem \%73,2 ile Ocak ayında en yüksek orandadır. Nisbi nem ortalamasının en düşük olduğu ay ise $\% 44,8$ ile Temmuz ayıdır. Yıllık ortalama nisbi nem değeri ise $\% 58,8^{\prime}$ dir. Baraj yapımı sonrası aylık ortalama nisbi nem \%78,2 ile Ocak ayında en yüksek orandadır. Nisbi nem ortalamasının en düşük olduğu ay ise $\% 42,1$ ile Temmuz ayıdır. Yıllık ortalama nisbi nem değeri ise $\% 61,3$ 'tür. Acıpayam istasyonunda, Denizli istasyonunda olduğu gibi baraj yapımından sonra yıllık ortalama sıcaklık değerlerinde $1^{\circ} \mathrm{C}^{\prime}$ lik bir artş̧ tespit edilmiştir. Yıllık ortalama nisbi nem değer- 
lerinde ise Denizli istasyonunda barajdan sonra azalma görülürken; barajdan uzakta bulunan Acıpayam istasyonunda artma görülmüştür.

Denizli istasyonunda baraj yapımı öncesi ve sonrasında aylık ortalama sıcaklıklar arasındaki fark en fazla $1,8^{\circ} \mathrm{C}$ ile Ağustos ayında gerçekleşmiştir. Genel manada yaz aylarındaki artış kış aylarınkinden daha fazladır. Baraj yapımından sonra aradaki aylık ortalama sıcaklık farkı çok değişmeyen aylar ise ilkbahar ve sonbahar aylarıdır. Acıpayam istasyonunda baraj öncesi ve sonrası aylık ortalama sıcaklık değerlerine bakıldığında $1^{\circ} \mathrm{C}^{\prime} l i k$ bir artışın olduğu, ay bazında ise $1,6^{\circ} \mathrm{C}^{\prime}$ lik artışla Temmuz ve Ağustos aylarında olduğu görülmektedir. Yıllık ortalama hissedilen sıcaklık değerleri de iki istasyonda da artşların $\left(0,8^{\circ} \mathrm{C}\right)$ olduğu görülmektedir. Özkan (1996) tarafindan yapılan Keban Baraj Gölü’nün iklime etkisi araştıran çalışmaya göre de baraj yapımından sonra kış aylarında sıcaklık değerlerinde kayda değer artş̧lar, yaz aylarında ise bir miktar azalma tespit edilmiştir. Ilısu Baraj Gölü'nün Diyarbakır ve Batman illerinin iklimine etkisini lineer regresyon yöntemleriyle inceleyen Batan (2012) ise sıcaklıkta kısmi artış ve azalışlar, nisbi nemde genelde azalmalar, buharlaşmada da kış aylarında azalma tespit edilmiş olup çalışma bulgularımıza destekler niteliktedir.

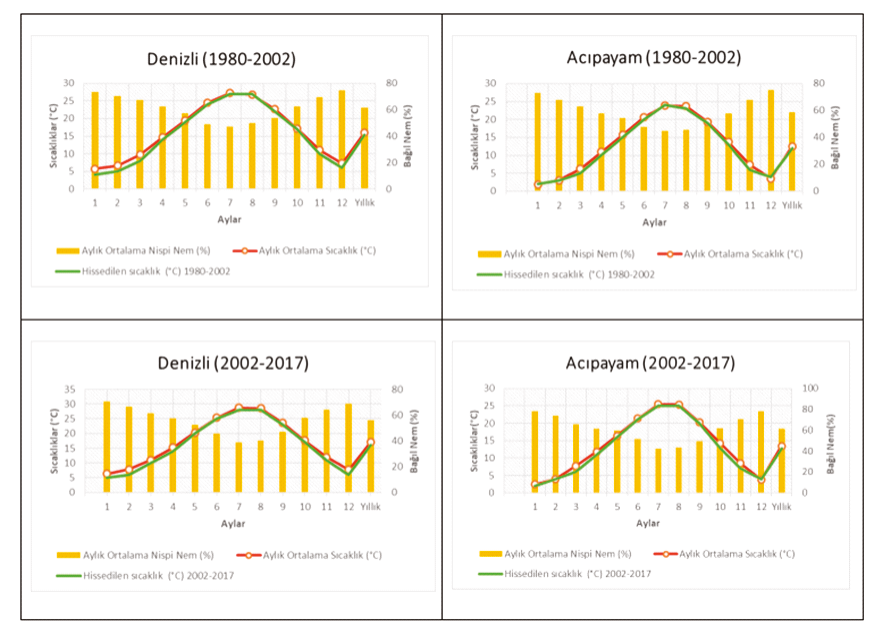

Şekil 2. Denizli ve Acıpayam meteoroloji istasyonu baraj yapımı öncesi ve sonrası iklim parametreleri

Figure 2. Denizli and Acıpayam meteorological station climate parameters before and after dam construction

Aylık ortalama nisbi nem oranlarında ise Denizli istasyonunda baraj yapımından sonra düşüşler görülmektedir. Özellikle yaz aylarında baraj yapımından sonra nisbi nem oranları arasındaki fark \%10'lar civarındadır. Değişimin en fazla olduğu ay Ağustos'tur. Ağustos ayından Eylül ayına geçerken baraj yapımı sonrasındaki nisbi nem farkı hızlıca azalmaktadır. Acıpayam istasyonunda ise Denizli istasyonunun aksine aylık ortalama nisbi nem değerlerinin yıllık ortalamasında baraj yapımından sonra \%2,5'lik bir artş̧ olduğu görülmektedir. Nem artışı Temmuz ve Ağustos ayları hariç diğer aylarda kaydedilirken, bu aylarda \%2,75 ve \%2,17'lik azalmalar görülmektedir (Şekil 2). Baraj yüzey hacmi nispeten küçük olan Akkaya Barajı́nın iklime olan etkisinin değerlendirildiği çalışmada da baraj sonrasında aylık ortalama nispi nem ve aylık ortalama rüzgar hızının azaldığını tespit edilmiştir (Arslan, 2017).

Denizli istasyonu aylık ortalama hissedilen sıcaklık değerlerine bakıldığında baraj yapımından sonra yaz aylarında $28^{\circ} \mathrm{C}^{\prime}$ yi geçmediği görülmektedir. Baraj yapımından önce ise $27^{\circ} \mathrm{C}^{\prime}$ yi aşmamaktadır. Acıpayam istasyonunda ise aylık ortalama hissedilen sıcaklık değerlerinin yıllık ortalamasında baraj öncesi ve sonrası $0,8^{\prime}$ lik bir artı̧ olduğu görülmektedir. Aylık hissedilen sıcaklık ortalamasının baraj öncesinde en fazla $24^{\circ} \mathrm{C}^{\prime}$ yi baraj sonrasında ise $25^{\circ} \mathrm{C}^{\prime}$ yi aşmadığı görülmektedir. Farkın en fazla artışın olduğu ay ise $2^{\circ} \mathrm{C}$ ile Ağustos ayıdır. Rüzgârın etkisi göz ardı edilerek oluşturulan grafiklerde kış aylarında hissedilen sıcaklığın baraj yapımından sonra daha yüksek olduğu görülmektedir. Aylık ortalama bağıl nemin yaz aylarında düştüğü ve kış aylarında yükseldiği gözlenmektedir. Her iki istasyonda da yıllık ortalama sıcaklık ve hissedilen sıcaklık değerlerinde artş görülürken; yıllık ortalama bağıl nem değerlerinde Denizli istasyonunda düşüş, Acıpayam istasyonunda da artı̧̧ olduğu görülmektedir. (Şekil 2).

\subsection{Denizli İstasyonu İklim Parametreleri İçin Bağımlı Değişkenlerde t Testi}

Denizli ve Acıpayam meteoroloji istasyonlarının her ikisinde de bağımlı değişkenlerde t testi sonucunda; aylık ortalama sıcaklık, aylık hissedilen sıcaklık ortalaması ve aylık ortalama nisbi nem parametreleri p:0,00<0,05 olduğundan baraj yapımından sonra anlamlı değişiklik olduğu hipotezi kabul edilmiştir. Ayrıca t değeri negatif sayı olan parametrelerde baraj yapımından sonra artı̧ olduğu, pozitif sayılarda ise azalış olduğu t testi tablosundan çıkarılan sonuçlardır (Tablo 1). Buna göre Denizli istasyonunda aylık ortalama nisbi nem değerlerinde baraj yapımından sonra azalma olduğu tespit edilmiştir. Aylık ortalama nisbi nem değeri baraj yapımından önce \%61,37 iken baraj yapımından sonra \%55,84 değerine düştüğü görülmektedir. Acıpayam istasyonunda ise değerlerin \%58,75'ten \%61.32'ye yükseldiği görülmektedir. İki istasyonda da baraj yapımı öncesi ve sonrası parametrelerde anlamlı değişiklik vardır.

Tablo 1. Denizli ve Acıpayam meteoroloji istasyonlarına ait bağımlı değişkenler $t$ testi sonuçları

Table 1. Denizli and Acıpayam meteorological station t test results of dependent variables

\begin{tabular}{|c|c|c|c|c|c|c|c|}
\hline \multirow{2}{*}{ Parametre } & \multirow{2}{*}{ Zaman } & \multicolumn{3}{|c|}{ Denizli İstasyonu } & \multicolumn{3}{|c|}{ Acıpayam İstasyonu } \\
\cline { 3 - 8 } & & $\mathbf{X}$ & $\mathbf{T}$ & $\mathbf{p}$ & $\mathbf{X}$ & $\mathbf{t}$ & $\mathbf{p}$ \\
\hline \multirow{2}{*}{ Aylık Ortalama Sicaklık } & Baraj Öncesi & 16,03 & $-7,99$ & 0,00 & 12,47 & $-7,95$ & 0,00 \\
\cline { 2 - 8 } & Baraj Sonrası & 17,00 & & & 13,45 & & \\
\hline \multirow{2}{*}{ Aylı Ortalama Nisbi Nem } & Baraj Öncesi & 61,37 & 9,79 & 0,00 & 58,75 & $-3,13$ & 0,01 \\
\cline { 2 - 8 } & Baraj Sonrası & 55,84 & & & 61,32 & & \\
\hline \multirow{2}{*}{ Ayllk Hissedilen Sicaklık } & Baraj Öncesi & 15,25 & $-5,00$ & 0,00 & 12,00 & $-4,00$ & 0,00 \\
\cline { 2 - 8 } & Baraj Sonrası & 16,08 & & & 12,83 & & \\
\hline
\end{tabular}

\subsection{Mann-Kendall Testi ve Sen Trend Eğim Metodu}

Mann-Kendall testi ve Sen Trend Eğim Metodu testlerinde \%95 güven aralığında $|z|>1,96$ ise sıfir hipotezi reddedilir. Yani incelenen zaman serilerinde trend mevcuttur. $Z$ değeri negatif ise artan yönde bir trendin, negatif ise azalan yönde bir trendin var olduğu söylenmektedir. Sıfir hipotezinin reddedildiği durumların haricinde zaman serisinde trendin olmadığı görülmektedir. Her iki meteoroloji istasyonun 1980-2002 ve 2002-2017 yıllarını kapsayan zaman serilerinde aylık ve yıllık ortalamalar alınarak Mann-Kendall testi uygulanmıştır.

Testin sonucunda yıllık ortalamalarına bakıldığında Denizli ve Acıpayam istasyonlarının sıcaklık ve hissedilen sıcaklık değerleri $|z|>1,96$ olduğundan \%95 güven aralığında zaman serilerinde pozitif yani artan bir trend olduğu görülmektedir. Denizli istas- 
yonu bağıl nem değerinde ise negatif yani azalan yönde bir trend olduğu görülmektedir. Acıpayam istasyonunda bağıl nem ortalamasında ise $|z|: 1,75<1,96$ olduğunda \%95 güven aralığında zaman serilerinde trend olmadığı görülmektedir. Her iki istasyonda da baraj öncesi ve sonrası iklim parametrelerindeki aylık değişimlere bakıldığında aylık ortalama sıcaklıklar ve aylık ortalama hissedilen sıcaklık değerlerinde baraj yapımı sonrası Temmuz ayında pozitif yönde bir trend olduğu görülmektedir. Ayrıca Denizli istasyonunda Mart ve Ekim, Acıpayam istasyonunda Mart ve Kasım aylarında da baraj yapımı sonrası aylık ortalama sıcaklıklar ve aylık ortalama hissedilen sıcaklık değerlerinde pozitif yönde bir trend vardır (Tablo 2).

Tablo 2. Denizli ve Acıpayam meteoroloji istasyonlarına ait Mann-Kendall test sonuçları

Table 2. Mann-Kendall test results of Denizli and Acıpayam meteorology stations

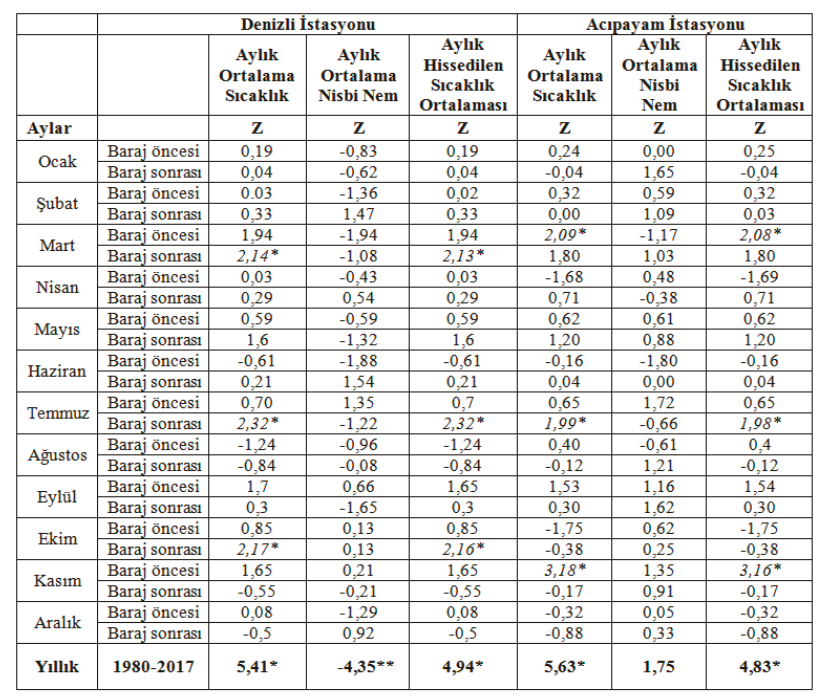

*: pozitif trend $* *$ : negatif trend

Denizli ve Acıpayam istasyonları iklim parametrelerinin baraj öncesi ve sonrası yıllık ortalamalarının Sen Trend Eğim Metodu sonuçlarına bakıldığında (Tablo 3) ortalama sıcaklık ve ortalama hissedilen sıcaklık değerlerinde trendin artma yönünde olduğu görülmektedir. Denizli istasyonunda ise ortalama bağıl nem değerinin azalma eğiliminde olduğu görülmektedir. Sen Trend Eğim Metodu grafiklerine bakıldığında da parametreler arasındaki eğim farkı görülmektedir. Denizli istasyonunun parametrelerinde artma ve azalma eğilimi Acıpayam istasyonun parametrelerinden daha fazladır. Ortalama sıcaklık ve hissedilen sıcaklık değerlerinde artma eğilimi Denizli istasyonunda daha fazladır (Şekil 3). İstasyonun ortalama sıcaklık değerleri değişimi Q:0,061>0,056 olduğundan, Acıpayam istasyonunda daha fazla olduğu Sen Trend Eğim Metodu sonucu baz alınarak söylenebilir. Aynı şekilde ortalama hissedilen sıcaklık değerlerinde değişimde Denizli istasyonunda daha fazladır. Bağımlı değişkenlerde t testi ve Mann-Kendall trend analizi teminde yöntemindede görüldüğü gibi Sen Trend Eğim Metodu'nda da ortalama bağıl nem değerlerinde Denizli istasyonunda azalış, Acıpayam istasyonunda artş̧ tespit edilmiştir (Tablo 3

Denizli istasyonu verilerine göre Gökpınar Baraj Gölü yapımı öncesi ve sonrası arasında hissedilen sıcaklık değerlerinde $t$ testi sonucunda anlamlı bir değişim olduğu, Mann-Kendall ve Sen Test sonuçlarında ise artma yönünde bir eğilim olduğu görülmektedir. Fakat Sen Trend Eğim Metodu Q değerlerine ba- kıldığında eğimin şiddetinin fazla olmadığı görülmektedir. Aynı şekilde Acıpayam istasyonu aylık ve yıllık ortalama hissedilen sıcaklık değerlerinde baraj yapımından sonra anlamlı bir değişimin olduğu ve sıcaklık değerlerinde artma yönünde bir eğilim olduğu görülmektedir.

Tablo 3. Denizli ve Acıpayam meteoroloji istasyonlarına ait Sen Trend Eğim Metodu sonuçları (1980-2017)

Table 3. Sen Trend Slope Method results of Denizli and Acıpayam meteorology stations(1980-2017)

\begin{tabular}{|c|c|c|c|c|c|c|}
\hline Sen Trend Eğim Metodu & \multicolumn{3}{|c|}{ Denizli İstasyonu } & \multicolumn{3}{c|}{ Acıpayam İstasyonu } \\
\hline Parametre & Q & Qmin95 & Qmax95 & Q & Qmin95 & Qmax95 \\
\hline $\begin{array}{c}\text { Ayllk Ortalama } \\
\text { Sicakllk }\end{array}$ & 0,061 & 0,043 & 0,079 & 0,056 & 0,043 & 0,071 \\
\hline $\begin{array}{c}\text { Ayllk Ortalama } \\
\text { Bağıl Nem }\end{array}$ & $-0,247$ & $-0,329$ & $-0,159$ & 0,100 & $-0,014$ & 0,234 \\
\hline $\begin{array}{c}\text { Ayllk Ortalama } \\
\text { Hissedilen Sicaklık }\end{array}$ & 0,072 & 0,051 & 0,095 & 0,074 & 0,048 & 0,096 \\
\hline
\end{tabular}

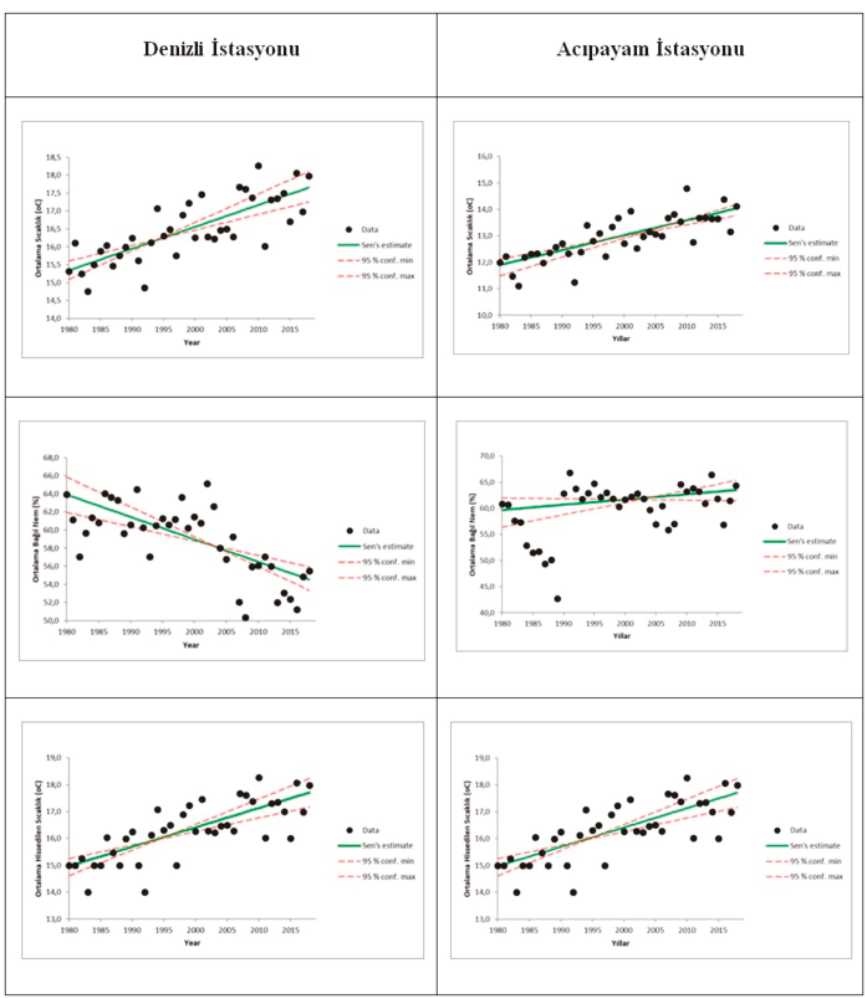

Şekil 3. Denizli ve Acıpayam meteoroloji istasyonları Sen Eğim Metodu sonucu grafikleri(1980-2017)

Figure 3. Denizli and Acıpayam meteorology stations Sen Slope Method result graphs (1980-2017)

Özdemir ve Bahadır tarafindan 2010 yılında yapılan çalışmada Denizli iline ait sıcaklık, buharlaşma ve yağış verileri Box-Jenkins tekniği ile 2015 yılına kadar değişim eğilimlerinin pozitif yönde anlamlı ilişkiler olduğunu tespit edilmiştir (Özdemir ve Bahadır, 2010). Yine Bacanlı ve Tuğrul'un (2015) yılında yaptığı çalışmada Gökpınar Baraj Gölü'nün iklimsel etkilerini lineer regresyon ile analiz etmişlerdir. Çalışmanın sonucunda ortalama sıcaklıklar, yağış, rüzgar hızı ve buharlaşma verileri trend denklemi eğiminin pozitif değerde olduğunu, sıcaklıkların ve rüzgar hızının arttğını tespit etmişlerdir. Tespit edilen bulgular bu çaIışmayla da örtüşmektedir. Fakat Türkiye'de aylık ortalama sıcaklık değişimleri ile ilgili yapılan çalışmalar (Acar Deniz \& Gönençgil, 2017; Acar, Gönençgil ve Korucu Gümüşoğlu, 2018; Cosun ve Karabulut, 2015; Türkeş, 1995; Türkeş, Sümer ve Demir, 2002) gösteriyor ki Türkiye'de sıcaklık değerlerinde anlamlı bir artış vardır. 
Bu bağlamda ortalama sıcaklık ve hissedilen sıcaklıklarda görülen artı̧ sadece baraj gölünün varlığıyla açıklanamaz. Bu çaIışmada da görüldüğü gibi Denizli ve Acıpayam istasyonunda ortalama sıcaklık ce hissedilen sıcaklık değerlerinde anlamlı bir artış trendi vardır. Ayrıca Özdemir ve Bahadır'ın (2010) yaptı̆ı çalışmada belirttiği gibi Denizli ilinde karasal etkiler olsa da Akdeni ziklimi baskındır.Bu bağlamda sıcaklıklarda ki artı̧ baraj etkisinden çok Akdeniz ikliminin küresel iklim değişikliğine bağlı sıcaklık artışı ile ilişkilendirilebilir.Meteoroloji Genel Müdürlüğü’nün bölgesel iklim modeli dinamik ölçek küçültme yöntemiyle 20 km çözünürlükte sıcaklık ve yağış projeksiyonlarına göre de $2016-2040$ periyodu ısınmanın genellikle $0,5^{\circ} \mathrm{C}-1,5^{\circ} \mathrm{C}$ arasında olacağı, yaz mevsiminde Ege ve Akdeniz bölgelerinde $1,5^{\circ} \mathrm{C}^{\prime}$ nin üzerinde bir artş̧ın olacağı hesaplanmıştır (MGM, 2015). Buna göre 37 yıllık süreyi ele alarak artş̧ olduğu görülmektedir. Bu bağlamda Denizli ve Acıpayam çevresindeki sıcaklık artışının küresel iklim değişiminden kaynaklı olabileceği, bağıl nem ortalamalarında değerlerin azalma eğiliminde olduğu tespit edilmiştir.

\section{Sonuç}

Çalışmanın sonucunda meteorolojik parametrelere bakıldığında hissedilen sıcaklıklarda iki istasyonda da artş̧ olduğu, bağıl nem oranlarının da Denizli istasyonunda azalma eğiliminde olduğu görülmektedir. Denizli Meteoroloji istasyonundan temin edilen 1980-2017 yıllarını kapsayan veriler barajın faaliyete geçtiği yıl kabul edilen 2002 yılından ikiye ayrılarak incelenmiştir. Baraj yapımından sonra ki geçen 15 yıllık periyotta ise sıcaklıkların çoğu aylarda arttı̆ı görülmektedir. Aylık ortalama sıcaklığın en yüksek olduğu ay $28,7^{\circ} \mathrm{C}$ ile Temmuz ayıdır. $\mathrm{Bu}$ da Akdeniz iklim karakteristiği olarak kışların ılık geçtiğini göstermektedir. Gökpınar Baraj Gölü yapımından önce ve sonra hissedilen sıcaklık değerlerinde belirgin bir farklılığın tespit edilememiş olması gölün çevre iklimi üzerinde hiç etkisi olmadığı anlamı taşımaz. Yeryüzünde farklı arazi örtüsü değişimi enerji bilançosu dolayısıyla iklim parametreleri üzerinde etkili olabilmektedir. Fakat bu tür arazi örtüsü üzerindeki değişimler o kadar küçük olabilir ki mevcut işlemler bu etkiyi göstermeyebilir. Denizli ve Acıpayam istasyonlarından elde edilen verilere göre aylık ortalama sıcaklık değerlerinde de olduğu gibi hissedilen sıcaklıklarda da aylık olarak $10 \mathrm{C}$ artış olduğu görülmektedir. Sıcaklıklarda ki artış ise barajın etkisinden çok bilimsel çalışmalarda bahsi geçen Akdeniz ikliminin küresel iklim değişikliğine bağlı sıcaklık artışı ve arazi örtüsünde meydana gelen değişiklikler ile açıklamak mümkündür.

Bu tür su kütleleri günün erken saatlerinde olduğu gibi sıcaklığın hızla artmaya başladığı zamanlarda serinletici etki, akşam saatleri gibi hava sıcaklığının hızla düştüğü zamanlarda ise çevrede ısıtıcı bir etki yapabilmektedir. Bu nedenle su kütlelerinin çevre iklimi üzerindeki etkilerini daha iyi analiz edebilmek için günlük ve hatta saatlik verilerle çalışılması daha belirgin sonuçlar sunabilecektir.

\section{Kaynakça}

Acar Deniz, Z., \& Gönençgil, B. (2017). Türkiye Sıcaklık Ekstremlerindeki Değişkenlikler. Coğrafya Dergisi,(35),41-54. https://dergipark.org.tr/tr/pub/iucografya/issue/32204/347083 adresinden alındı

Acar, Z., Gönençgil, B., \& Korucu Gümüşoğlu, N. (2018). Long-Term Changes in Hot and Cold Extremes in Turkey. Coğrafya Dergisi https://dergipark.org.tr/tr/pub/iucografya/issue/41595/502497 adresinden alındı

Agoramoorthy, G., \& Hsu, M. J. (2016). Small Dams Revive Dry Rivers and Mitigate Local Climate Change in India's Drylands . International Journal of Climate Change Strategies and Management,271285.

Anonim. (2019). Mann-Kendall Test For Monotonic Trend. Visual Sample Plan: https://vsp.pnnl.gov/help/Vsample/Design_Trend_Mann_Kendall.htm adresinden alındı

Arslan, O. (2017). Akkaya Barajının Niğde ili İklimine Etkisi. Ömer Halisdemir Üniversitesi Mühendislik Bilimleri Dergisi, Cilt 6, Sayı 2, 627-633.

Ashrae. (1997). Fizyolojik illkeler ve Isıl Konfor. Ç. O. Genceli içinde, Ashrae Temel El Kitabı (s. Bölüm 8). Tesisat Mühendisleri Derneği Teknik Yayınlar:2.

Bacanlı , Ü. G., \& Tuğrul, A. T. (2015). Baraj Göllerinin Iklimsel Etkisi ve Vali Recep Yazıcıoğlu Gökpınar Baraj Gölü Örneği. Pamukkale Üniversitesi Mühendislik Bilimleri Dergisi, 154-159.

Batan, M. (2012). “Diyarbakır ile Batman İlleri İklim Verilerinin Lineer Regresyon ile Karşılaştrııması ve Ilısu Barajı Sonrası Batman ilinin Gelecek İklim Verilerinin Elde Edilmesi. Batman Üniversitesi Yașam Bilimleri Dergisi, 225-232.

Büyüköztürk, Ş. (2002). Sosyal Bilimler için Veri Analizi El Kitabı. Ankara: Pegem Akademi.

Chao, B. (1995). Anthropogenic impact on global geodynamics due to reservoir water impoundment. Geophysical Research Letters 22(24), 3529-3532.

Cosun, F., \& Karabulut, M. (2015). Kahramanmaraş'ta ortalama, minimum ve maksimum sıcaklıkların trend analizi. Türk Coğrafya Dergisi,

(53),

41-50.https://dergipark.org.tr/tr/pub/tcd/issue/21228/227810 adresinden alındı.

Darkot, B., \& Tuncel, M. (1995). Ege Bölgesi Coğrafyası. İstanbul: Edebiyat Fakültesi Basımevi.

Degu, A. M., Hossain , F., Niyogi, D., Pielke , R., \& Shepherd , J. M. (2011). The Influence of Large Dams on Surrounding Climate and Precipitation Patterns. Geophysical Research Letters, 1-7.

Demirpençe, H., \& Güldal, V. (2001). Manavgat ve Oymapınar Baraj Göllerinin Yakın Çevre İklimine Etkisi. 1. Türkiye Su Kongresi , (s. 347-354). İstanbul.

DenizliHaber. (2014, Eylül 21). "Gökpınar Taşınacak" Dedikodusu. (Ş. Boz, Dü.) Denizli. https://www.denizlihaber.com/denizli/kentgenel/gokpinar-tasinacak-dedikodusu/ adresinden alındı

Erdaş, O., Yüksel, A., \& Başaran, M. (2001). K.Maraş Yöresindeki Barajların İklim Üzerindeki Etkilerinin Araştrııması. 1. Türkiye Su Kongresi , (s. 355-362). İstanbul.

Esterby, S. (1996). Review of methods for the detection and estimation of trends with emphasis on water quality applications. Hydrological Processes 10:, 127-149.

Gilbert, R. (1987). Statistical Methods for Environmental Pollution Monitoring. NY: Wiley.

Golbabaei, F., Heidari, H., Sihamsipour, A., Forushani, A. R., \& Gaeini, A. (2019). A new outdoor environmental heat index (OEHI) as a simple andapplicable heat stress index for evaluation of outdoor workers. Urban Climate 29 , 1-10

Göney, S. (1975). Büyük Menderes Bölgesi . İstanbul: Edebiyat Fakültesi Matbaası.

Güldal, V., \& Ağıralioğlu, N. (1994). Baraj haznelerinin iklime etkisi: Keban barajı. Su ve Toprak Kaynaklarını Geliştirme Konferansı (s. 417- 435). Ankara: DSi.

Hirsch, R., Slack, J., \& Smith, R. (1982). Techniques of trend analysis for monthly water quality data. Water Resources Research 18(1), 107-121.

ÇDR. (2016). il Çevre Durum Rapoları. Denizli: Çevre ve Şehircilik Bakanlığı.

iiçDR. (2017). Denizli. Ankara: Çevre ve Şehircilik Bakanlığı.

Jermar, M. K. (1987). Water Resources and Water Management. Developments in Water Science . içinde Amsterdam: Elsevier Science 
Publ. B.V. .

Kadıoğlu, M., \& Şen, Z. (1994). Keban Barajı Öncesi ve Sonrasında Çevre Iklminin Fraktal Analizi. Son değerlendirmeler ışığında Keban Brajı'nın Elazığ iklimine etkisi'ni (s. 1145-1155). Ankara: DSi.

Kadıoğlu, M., Satılmış, S., \& Özgüler, H. (1994). Büyük su yapılarının çevre iklimine etkisi. Su ve Toprak Kaynaklarının Geliştirilmesi Konferansı (s. 1099-1107). Ankara: DSi.

Kendall, M. (1975). Rank Correlation Methods. Lonon: Charles Griffin.

Koçman, A. (1993). Ege Ovalarının Iklimi. İzmir: Ege Üniversitesi Yayınları.

Mann, H. (1945). Non-parametric tests against trend. Econometrica 13, 163-171.

MGM. (2015). Yeni Senaryolar ile Türkiye Iklim Projeksiyonları Ve Iklim Değişikliği. Ankara: Meteoroloji Genel Müdürlüğü Matbaası.

MGM, M. (2018). Hissedilen Sıcaklık (Sıcaklık ve Neme Göre) ve Rüzgar Etkisi (Wind chill). Meteoroloji Genel Müdürlüğü: https://www.mgm.gov.tr/genel/sss.aspx?s=hissedilensicaklik adresinden alındı

NOAA. (2014, Mayıs 28). Heat Index Calculation. National Weather Science Weather Prediction Center https://www.wpc.ncep.noaa.gov/html/heatindex_equation.shtm I adresinden alındı

Özdemir, M., \& Bahadır, M. (2010). “Denizli'de Box-Jenkins tekniği ile küresel iklim değişikliği öngörüleri. The Journal of International Social Research, 3(12), 352-362.

Özkan, F. (1996). Keban Baraj Gölü'nün Elazığ Bölgesi Iklim Şartlarına Etkisinin Araşttrılması. Elazığ: Yüksek Lisans Tezi, Fırat Üniversitesi.

Gyau-Boakye, P. (2001). Environmental impacts of the Akosombo dam and effects of climate change on the lake levels . Environment, Development and Sustainability 3(1), 17-29.

Rothfusz, L. (1990). The Heat Index Equation. Western Region Technical Attachment.

Sen, P. K. (1968). Estimates of the regression coefficient based on Kendall's tau. J Am Stat As 63, 1379-1389.

Stapleton, S. O., Sabbag, L., Hawley, K., Tran, P., Hoang, L., \& Nguyen, P. (2016). Heat index trends and climate change implications for occupational heatexposure in Da Nang, Vietnam. Climate Services 2-3, 41-51.

Steadman, R. (1979). Indices of windchill of clothed persons. Journal of Applied Meteorology, cilt. 10, no 4, 674-683.

Steadman, R. (1979a). A temperature-humidity index based on human physiology and clothing science. The assessment of sultriness (s. 861-873). içinde

Steadman, R. (1984). A universal scale of apparent temperature. J. Clim. Appl. Meteorol., 23 , 1674-1687.

Sungur, K. (1980). Türkiye'de İnsan Yaşamı Açısından Uygun Olan Ve Olmayan Isı Değerlerinin Aylık Dağılışı ile İlgili Bir Deneme. İstanbul Üniversitesi Coğrafya Enstitüsü Dergisi 23, 27-36.

Şengün, M. T. (2007). Son Değerlendirmeler Işığında Keban Barajı'nın Elazığ İklimine Etkisi. Doğu Anadolu Bölgesi Araşttrmaları, 116121.

Temur, T. (2017). Susurluk Havzası Sıcaklık ve Yağış Trendleri. 4. iklim Değişikliği Kongresi . İstanbul.

Tonbul, S. (1986). Elazığ ve çevresinin iklim özellikleri ve Keban barajının yöre iklimi üzerine olan etkileri. Fırat Üniversitesi Coğrafya Sempozyumu (s. 275-293). Elazığ: Fırat Üniversitesi.

Türkeş, M. (1995). Türkiye'de Yıllık Ortalama Hava Sıcaklıklarındaki Değişimlerin ve Eğilimlerin İklim Değişikliği Açısından Analizi. Çevre ve Mühendislik Dergisi 9, 9-15.

Türkeş, M., Sümer, U., \& Demir, İ. (2002). Türkiye'nin Günlük Ortalama Maksimum ve Minimum Hava Sıcaklıkları İle Sıcaklık Genişliğindeki Eğilimler ve Değişiklikler. 11-13 Nisan Klimatoloji Çalıştayı Bildiriler Kitabı, (s. 89-106). İzmir.

Ünlü, O. (2018). Zirveden Gökpınar Baraj Gölü. http://www.fotografturk.com/zirveden-gokpinar-baraj-golu-denizli-p460917 adresinden alındı
Xiutai, W. (1986). Environmental Impact of the Sanman George Project. Water Power and Dam Construction. içinde November.

Yeşilnacar, I., \& Gülşen , H. (1999). Şanlıurfa ve Çevresinin İklim Özellikleri ve Atatürk Barajının Yöre İklimi Üzerindeki Etkileri. 52. Türkiye Jeoloji Kurultayı, (s. 122-128). Ankara.

Zaiontz, C. (2012). Sen's Slope. Real Statistics Using Excel: https://www.real-statistics.com/time-series-analysis/time-series-miscellaneous/sens-slope/ adresinden alındı 